\title{
The Relationship between Rural Endowment Insurance and Rural Human Capital Investment : A Exploratory Study of hebei Province, P. R. China
}

\author{
Sun Yifan ${ }^{a^{*}}$, Chen Lishaa, Amran Raslib \\ ${ }^{a}$ Faculty of Management, Universiti Teknologi Malaysia, 81310 UTM Johor Bahru, Johor, Malaysia \\ ${ }^{b}$ Admin Office D05, Faculty of Management, Universiti Teknologi Malaysia, 81310 UTM Johor Bahru, Johor, Malaysia \\ *Corresponding author: yfsun510@gmail.com
}

Article history

Received :4 April 2013

Received in revised form :

25 July 2013

Accepted :15 October 2013

\begin{abstract}
In China, Elderly care of rural residents is a heavy burden for Chinese government. The inadequate of rural endowment insurance has resulted in the deficiency of education investment for the next generation, and in some poor families children even lost their chance of going to school. Therefore, it's necessary to study the relation between rural endowment insurance and human capital. In 2009, a reform has begun. The contribution has been cut into 3 parts, rural residents only need to pay one third; the other 2 parts are paid by the government of the country and local village. 3 years past, this paper used regression analysis to see if the reform improved rural human capital investment, the result showed that there is no significant correlation. The government should do more work on publicity to let rural residents know the policy of new rural endowment insurance, to let them sure that they needn't worry about their old age life quality.
\end{abstract}

Keywords: Rural; endowment insurance; human capital investment

\subsection{INTRODUCTION}

China has a population of 1.3 billion, of which, around $66 \%$ are rural residents (China Statistical Yearbook, 2010). Elderly care of rural residents is a heavy burden for Chinese government. The inadequate of rural endowment insurance has resulted in the deficiency of education investment for the next generation, and in some poor families children even lost their chance to go to school. Therefore, it's necessary to study the relationship between rural endowment insurance and human capital investment. Since New Growth Theory (Lucas, 1988 and Romer, 1990) was formed, human capital, no less than physical capital, was regarded as an important element for economic growth. Lots of economics and sociologists began to study on the relationship between human capital investment and endowment insurance from different perspectives. Under the pay-as-you-go system, the pension of last generation can be paid by the next generation who are working (Li, 2001). This means that the pension of old generation is directly correlated with the income of young generation. Zhang (1995) found that an unfunded program may stimulate growth by reducing fertility and increasing the ratio of human capital investment per child to per family income when bequests are positive. On the other hand, there are some dissenting opinions. Ehrlich (1998) believes that endowment insurance of pay-as-yougo system has different influence on fertility, human capital investment and family savings in different phases of economic development. In the initial period of economic development, endowment insurance of pay-as-you-go system had negative impact on fertility, however, when the economic development speed up, the fertility of population has become very low, so endowment insurance has little influence on fertility but it will hinder the accumulation of human capital and economic growth. While in funded endowment insurance system, the young generation needs to accumulate money for their retirement, it will result in the rise of fertility and the decline of per capita education level (Stuart, 1998).

\subsection{DATA AND METHODS}

In Hebei Province, social endowment insurance for urban workers is better than rural endowment insurance and its coverage is more extensive. Based on the data of 2008, the number of employee in urban areas in Hebei Province is 7.5 million and the subscriber number of urban endowment insurance is 6.4 million. The insured proportion reached $85.2 \%$. In 2009, Ministry of Human Resources and Social Security of P. R. China enacted New Rural Social Endowment Insurance Handling Procedure, and a reform has begun. The government of Hebei Province defined that all local rural residents (students are not included), who are over 16 years old can subscribe to it. The contribution has been cut into 3 parts, rural residents only need to pay one third; the other 2 parts are paid by the government of the country and local village. 
This paper used the data of Hebei Province from 2001 to 2010 and analyzed by regression analysis with SPSS, to find the relation between social endowment insurance, rate of saving, urban human capital investment and rural human capital investment.

Based on Zhao's (2011) research and her model, this paper selected 5 variables: Per Capita Education Expenditure of Rural
Residents (EER), Annual Per Capita Net Income of Rural Households (IR), Balance of Savings Deposit of Rural and Urban Residents (year-end) (S), Per Capita GDP (PG), Endowment Insurance Contribution Rate of Rural Residents (R) and Per Capita Education Expenditure of Urban Residents (EEU) (refer to Table 1) (Hebei Economy Yearbook, 2001-2010).

Table 1 Relevant data of economy and endowment insurance of Hebei province

\begin{tabular}{lllllll}
\hline & EER (CNY) & IR (CNY) & S (100 Million CNY) & PG (CNY) & R & EEU (CNY) \\
\hline 2000 & 130.71 & 2478.86 & 3957.06 & 7592.0 & 0.121 & 529.35 \\
2001 & 139.22 & 2603.6 & 4364.2 & 8251.0 & 0.1152 & 498.06 \\
2002 & 156.91 & 2685.16 & 4811.3 & 8960.0 & 0.1117 & 603.51 \\
2003 & 186.46 & 2853.29 & 5457.0 & 10251.0 & 0.1051 & 682.87 \\
2004 & 182.56 & 3171.06 & 6207.5 & 12487.0 & 0.0946 & 660.6 \\
2005 & 134.77 & 3481.64 & 7084.03 & 14659.0 & 0.0862 & 795.43 \\
2006 & 265.38 & 3801.82 & 8014.16 & 16682.0 & 0.0789 & 827.72 \\
2007 & 243.3 & 4293.43 & 8922.41 & 19662.0 & 0.0699 & 895.06 \\
2008 & 250.07 & 4795.46 & 11435.6 & 22986.0 & 0.0626 & 946.38 \\
2009 & 263.53 & 5149.67 & 13551.1 & 24581.0 & 0.0583 & 982.21 \\
2010 & 344.25 & 5957.98 & 15678.4 & 28668.0 & 0.0504 & 1001.01 \\
\hline
\end{tabular}

\section{$\mathrm{EER}=\beta_{0}+\beta_{1} \mathrm{IR}+\beta_{2} \mathrm{~S}+\beta_{3} \mathrm{PG}+\beta_{4} \mathrm{R}+\beta_{5} \mathrm{EEU}$}

Regression analysis is a statistical tool for the investigation of relationships between dependent variables and independent variables. Usually, the researcher seeks to ascertain the causal effect of one variable upon another (Sykes, 1988). In this paper, regression analysis was used.

\subsection{RESULTS}

In this research the relation among Per Capita Education Expenditure of Rural Residents, Annual Per Capita Net Income of Rural Households, Balance of Savings Deposit of Rural and
Urban Residents (year-end), Per Capita GDP, Endowment Insurance Contribution Rate of Rural Residents and Per Capita Education Expenditure of Urban Residents was measured through regression analysis by SPSS.

The result of regression analysis of the variables is shown in Table 2, and we have the regression formula:

\section{$\mathrm{EER}=30.527+0.367 \mathrm{IR}-0.013 \mathrm{~S}-0.056 \mathrm{PG}-3152.895 \mathrm{R}+0.091 \mathrm{EEU}$}

Table 2 showed that per capita education expenditure of rural residents is most correlated to annual per capita net income of rural households and per capita GDP. There is no significant correlation between per capita education expenditure of rural residents and other 3 independent variables.

Table 2 Coefficients ${ }^{\mathrm{a}}$ of regression analysis

\begin{tabular}{|c|c|c|c|c|c|c|}
\hline \multirow{2}{*}{\multicolumn{2}{|c|}{ Model }} & \multicolumn{2}{|c|}{ Unstandardized Coefficients } & \multirow{2}{*}{$\begin{array}{c}\begin{array}{c}\text { Standardized } \\
\text { Coefficients }\end{array} \\
\text { Beta }\end{array}$} & \multirow[b]{2}{*}{$\mathbf{t}$} & \multirow[b]{2}{*}{ Sig. } \\
\hline & & B & Std. Error & & & \\
\hline \multirow[t]{6}{*}{1} & (Constant) & 30.527 & 869.621 & & .035 & .973 \\
\hline & IR & .367 & .380 & 6.178 & .967 & .378 \\
\hline & $\mathrm{S}$ & -.013 & .033 & -.713 & -.388 & .714 \\
\hline & GDP & -.056 & .073 & -5.893 & -.775 & .473 \\
\hline & $\mathrm{R}$ & -3152.895 & 6250.501 & -1.124 & -.504 & .635 \\
\hline & EEU & .091 & .412 & .238 & .220 & .834 \\
\hline
\end{tabular}

a. Dependent Variable: EER

\subsection{CONCLUSION}

This research proved that the current rural endowment insurance scheme is not promoting rural residents use more money in human capital investment. (a) Per capita education expenditure of rural residents is most correlated with annual per capita net income of rural households and per capita GDP. It means that only when rural residents earn more money, or they won't put more money in human capital investment. 
(b) Per capita education expenditure of rural residents is not correlated with balance of savings deposit of rural and urban residents (year-end) and endowment insurance contribution rate of rural residents. The balance of savings deposit of rural and urban residents kept growing, rural resident is becoming more and more rich, but they didn't put more money in human capital investment. There are 2 points that can explain why the endowment insurance contribution rate cannot impact rural human capital investment. Firstly, the amount of endowment insurance contribution is stable and small, so the impact is small in the beginning. Then, the new rural endowment insurance has been just implemented for 3 years. Though rural residents subscribed rural endowment insurance, they still believe that they must save money themselves, but not they can get enough benefit from rural endowment insurance for their life in old age. (c) The government should do more work on publicity to make rural residents understand the policy of new rural endowment insurance, to let them sure that they needn't worry about their old age life quality. The government also should make sure that the benefit of rural endowment insurance can be issued as and when they should be issued. A few years later the situation will be changed.

\section{References}

[1] China Statistical Yearbook. 2010. Beijing. National Bureau of Statistics of China.

[2] Lucas, R. 1988. On the Mechanics of Economic Development. Journal of Monetary Economics. 22(1): 3-42.

[3] Romer, P. 1990. Endogenous Technological Change. Journal of Political Economy. 98(5): S71-S102.

[4] Li, J. 2001. Social Security Theory. Beijing. China Labor and Social Security Press. 209-212.

[5] Zhang, J. 1995. Social Security and Endogenous Growth. Journal of Public Economics. 2: P185-213.

[6] Ehrlich, I. and Zhong, J. 1998. Social Security and the Real Economy: An Inquiry into Some Neglected Issues. The American Economic Review. 2: P151-157.

[7] Stuart, E. 1998. Network Positions and Propensities to Collaborate: An Investigation of Strategic Alliance Formation in a High-technology industry. Administrative Science Quarterly. 43: P668-698.

[8] New Rural Social Endowment Insurance Handling Procedure. 2009. Ministry of Human Resources and Social Security of P. R. China.

[9] Zhao, C. 2011. New Rural Endowment Insurance in Xingtai City, Hebei Province. PhD. Thesis of Shanxi University of Finance and Economics.

[10] Hebei Economy Yearbook. 2001-2010. Beijing. National Bureau of Statistics of China. 